Grzegorz EMBROS

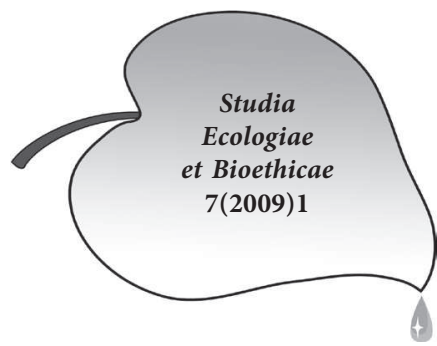

\title{
Audyt zachowań jako narzędzie systemu zarządzania bezpieczeństwem i higieną pracy
}

\begin{abstract}
Wstęp
Problematyka ochrony środowiska koncentruje się obecnie na takich aspektach jak ochrona wody, gleby, powietrza itp. Często można odnieść wrażenie, że cała problematyka jest sprowadzana (redukowana) wyłącznie do tych aspektów. $\mathrm{W}$ związku z tym, ochrona środowiska jest utożsamiana $\mathrm{z}$ ochroną przyrody czy inżynierią środowiska. Tymczasem ochrona środowiska ma charakter interdyscyplinarny. Ujmuje bardzo szerokie spektrum zagadnień i problemów często wykraczających poza obszar wymienionych dziedzin. Mówi się, w tym kontekście, o potrzebie ujęcia holistycznego czy systemowego. W takim przypadku można odwołać się do teorii systemów, w której podstawowym elementem jest system wraz z jego otoczeniem. Pomiędzy systemem a otoczeniem zachodzą wzajemne relacje (oddziaływania) o charakterze dynamicznym. W otoczeniu systemu mogą znajdować się inne systemy, z którymi system może również oddziaływać. Oddziaływania (sprzężenia) pełnią funkcję integrującą system $\mathrm{z}$ jego otoczeniem lub innymi systemami. Przykładem systemu może być człowiek (społeczeństwo - jako system wielki) a otoczenia - środowisko, w którym ów system funkcjonuje. Ujęcie takie pozwala na uwzględnienie, w problematyce ochrony środowiska, znaczenia stanu relacji (wzajemnych oddziaływań) występujących pomiędzy systemem (społeczeństwem) a otoczeniem (środowiskiem, w którym system funkcjonuje).

W kontekście sytuacji kryzysu ekologicznego pojawia się problem ryzyka i bezpieczeństwa, gdy zaburzeniu ulegają relacje pomiędzy człowiekiem (społeczeństwem) a środowiskiem (np. przyrodą). Człowiek oddziałując negatywnie na środowisko powoduje uruchomienie sprzężenia zwrotnego. Środowisko zmieniane przez człowieka, negatywnie oddziałuje na niego. Proces ten skutkuje pogarszaniem jakości życia wynikającego ze złego stanu środowiska. Pojawiają się choroby cywilizacyjne. Na znaczeniu zyskuje zainteresowanie społeczeństwa dobrym stanem zdrowia i poprawą jakości życia w otoczeniu. Przy czym śro-
\end{abstract}


dowisko to już nie tylko środowisko przyrodnicze ale także środowisko pracy, środowisko rodzinne, społeczne itp.

Świadomość obniżania jakości życia i zdrowia prowadzi do poszukiwań odpowiednich oraz adekwatnych narzędzi mogących przyczyniać się do zmiany tego stanu rzeczy. Wiele ciekawych propozycji związanych jest $\mathrm{z}$ ideą zrównoważonego rozwoju. Bazują na niej aktualne, bardziej skonkretyzowane propozycje działań. Począwszy od dyrektyw UE i zapisów prawnych a skończywszy na rozmaitych politykach, strategiach czy programach ochrony środowiska. Częstokroć skutkują one definiowaniem, wdrażaniem i realizacją projektów o charakterze lokalnym. Przejawem ich są konkretne działania praktyczne mające przyczynić się do poprawy relacji człowiek- otoczenie. Programy takie winny uwzględniać równocześnie problematykę ochrony przyrody (merytoryczne podstawy oparte o wiedzę pochodzącą z nauk przyrodniczych) jak i aspekt humanistyczny (wiedza z obszaru nauk o człowieku, nauk humanistycznych). U podstaw skutecznych działań winna znaleźć się usystematyzowana wiedza specjalistyczna. Niezwykle istotna jest, w tym kontekście, problematyka nauczania i wychowania. Na znaczeniu zyskuje odpowiednie kształtowanie postaw człowieka w stosunku do środowiska (w najszerszym rozumieniu tego terminu). Ważną rolę odgrywa tu edukacja środowiskowa. Przykładem projektu, w którym uwzględnia się powyższe uwagi może być nowatorski program audytów zachowań.

W organizacjach opracowywane i wdrażane są systemy zarządzania środowiskowego, systemy bezpieczeństwa, jakości itp. Zarządzanie środowiskowe polega na zarządzaniu ryzykiem środowiskowym w oparciu o ciągły monitoring prawa ochrony środowiska i pomiary emisji do środowiska. Na tej podstawie planowane są działania mające na celu zminimalizowanie negatywnego oddziaływania organizacji na środowisko. Ważnym walorem właściwie skonstruowanych, wdrażanych i utrzymywanych systemów zarządzania jest możliwość ich integracji. Dzięki niej możliwe jest uwzględnianie, $w$ omawianej problematyce, bardzo szerokiego spektrum zagadnień i realnych problemów. Możliwy jest odpowiedni podział kompetencji pomiędzy specjalistów a co najistotniejsze, skuteczne działanie na rzecz ochrony środowiska. Przykładem może tu być integracja systemu zarządzania środowiskowego z systemami zarządzania jakością czy zarządzania finansami ale także systemem zarządzania bezpieczeństwem pracy. Ten ostatni system staje się obecnie jednym $\mathrm{z}$ istotnych elementów ochrony środowiska. Koncentruje się bowiem na ochronie człowieka w miejscu pracy. Wobec tego dotyczy ochrony życia i zdrowia człowieka w otoczeniu (środowisku), w którym spędza on obecnie większą część życia.

\section{Zasady prowadzenia audytów zachowań niebezpiecznych}

Behawioralne aspekty bezpieczeństwa powinny stanowić integralny element zarządzania bezpieczeństwem i higieną pracy. Problemy związane z niebez- 
piecznymi zachowaniami pracowników mogą wskazywać na stopień wdrożenia i zrozumienia systemu zarządzania bezpieczeństwem. Nie jest bowiem istotne, z punktu widzenia bezpieczeństwa, czy dana jednostka organizacyjna posiada wdrożony i certyfikowany system zarządzania bezpieczeństwem, ale jak go realizuje i czy faktycznie pracownicy postępują $\mathrm{w}$ sposób określony w procedurach ${ }^{1}$. Zachowania pracowników mogą więc świadczyć o skuteczności wdrożenia systemu oraz o jego adekwatności w stosunku do realiów panujących w danej organizacji a także stanowić wskaźnik poziomu kultury bezpieczeństwa organizacji. Statystyki zdarzeń wypadkowych w środowisku pracy wskazują, że w 80-90\% wszystkich analizowanych wypadków zachowanie pracownika stanowi przyczynę pośrednią lub bezpośrednią zdarzenia wypadkowego. ${ }^{2}$

Obserwacja niebezpiecznych zachowań stanowi przykład programu mającego na celu modyfikację zachowań niebezpiecznych u pracowników. Może ona przybierać formę tzw. audytów zachowań (audytów behawioralnych). Johan Roels, założyciel Loss Control Centre w Belgii definiuje audyt behawioralny jako „[... metodę wpływania na bezpieczne zachowania i zachowania zagrażające bezpieczeństwu poprzez obserwację i dialog. Działania te standardowo przeprowadzane są na bazie wzajemnych interakcji (włączając komunikację typu każdy z każdym)"3.

Poniżej przedstawiono definicje głównych pojęć używanych w artykule. Opracowane zostały one na podstawie raportu Health and Safety Executive „Practical guide for behavioural change in UK oil and gas industry” z 2000 roku.

Behawioralne aspekty bezpieczeństwa - termin obejmuje wszystkie nietechniczne aspekty związane $\mathrm{z}$ bezpieczeństwem $\mathrm{i}$ higieną pracy i dotyczy np. sposobu, w jaki organizacja zarządza bezpieczeństwem oraz czynników wpływających na to, jak system zarządzania bezpieczeństwem funkcjonuje w rzeczywistości.

Kultura bezpieczeństwa - termin odnoszący się do wartości i postaw prezentowanych przez wszystkich członków organizacji w stosunku do kwestii dotyczących bezpieczeństwa.

Zachowanie - każde działanie lub brak działania możliwe do zaobserwowania, podejmowane lub zaniechane przez człowieka.

Bezpieczne zachowanie - każde zachowanie ukierunkowane na bezpieczeństwo np. stosowanie środków ochrony indywidualnej, rozmowa z współpracownikiem o kwestiach bezpieczeństwa.

Konsekwencje zachowania - skutki działań podejmowanych przez daną osobę; skutek określonego sposobu zachowania się.

\footnotetext{
1 Por. J. Reason, Managing the risks of organizational accidents, Ashgate, Aldershot 1998; Changing Minds- a practical guide for behavioural change in oil and gas industry. Step Change, Report for the Health and Safety Executive, Aberdeen 2000.

Por. J. Roels, Zasady stosowania audytów behawioralnych, w: Promotor 2008, 1-2, s. 15.

Por. Tamże.
} 
Program modyfikujący zachowania - szereg technik zaprojektowanych do tego aby zachęcać lub zniechęcać do z góry określonych zachowań.

Audyt zachowań polega na obserwacji zachowania związanego $\mathrm{z}$ bezpieczeństwem pracy (np. stosowanie określonych środków ochrony indywidualnej), oraz uświadomieniu pracownikowi konsekwencji działań. Osoba prowadząca audyt skupia się na sposobie wykonania zadania, pracy a nie na osobie pracownika. Dodatkowo osoba przeprowadzająca audyt zachowań wypełnia kartę obserwacji. Taki zapis pozwala na dokonanie analizy zachowania pracownika $\mathrm{w}$ danych warunkach i przy danym rodzaju pracy a co za tym idzie, na wskazanie możliwości doskonalenia systemu zarządzania bezpieczeństwem. Jak podkreśla Gabriela Maciejewicz „ programy obserwacji nastawione są na poszukiwanie odpowiedzi na pytania: Dlaczego ludzie zachowują się ryzykownie? Jakie bariery nie pozwalają im pracować $\mathrm{w}$ sposób bezpieczny? W związku z postawionymi pytaniami analizujemy otrzymane w programie dane, wyciągając wnioski i eliminując bariery".

Należy przy tym pamiętać, że programy modyfikowania zachowań bazujące na obserwacji nie mogą być alternatywą dla konwencjonalnego zarządzania bezpieczeństwem i higieną pracy. Te dwa podejścia powinny być stosowane równolegle. Zmiana zachowań nie jest bowiem prawdopodobna bez uwzględnienia środowiska pracy i czynników organizacyjnych. Wręcz przeciwnie, jak twierdzi Johan Roels inicjatywa taka może być postrzegana przez pracowników, jako unikanie przez kadrę zarządzającą nakładów inwestycyjnych na usprawnienia w zakresie bezpieczeństwa a w konsekwencji prowadzić do postrzegania programu obserwacji zachowań, jako wygodnego sposobu na unikanie przez kierownictwo odpowiedzialności. ${ }^{5}$

Aby uniknąć tego typu „pułapek”, wdrożenie programu modyfikującego zachowania pracowników (np. programu audytów zachowań), w jednostce organizacyjnej powinno być poprzedzone oceną systemu zarządzania bezpieczeństwem i higieną pracy. Program powinien być adekwatny do poziomu kultury bezpieczeństwa w danej organizacji. Niezbędne jest też zaangażowanie kierownictwa i samych pracowników, którzy powinni rozumieć założenia i cele programu. Bardzo ważnym czynnikiem warunkującym sukces programu jest szkolenie audytorów, w czasie którego uczą się, jak prowadzić obserwacje, na jakie zachowania zwracać uwagę, jak prowadzić dialog z pracownikiem i wskazywać na skutki zachowań niepożądanych. Audytorami zachowań mogą być zarówno pracownicy, jak i kierownicy. W większości tego typu programów opracowywana jest lista zachowań krytycznych dla bezpieczeństwa. Na tej podstawie można sporządzić listę kontrolną, na której audytor zaznacza zachowania niebezpieczne obserwowanego pracownika. Ostatnim elementem poprzedzającym wdrożenie programu

G. Maciejewicz, BOP-ersi w stużbie BHP, w: Promotor 2008, 1-2, s. 20.

Por. J. Roels, Zasady stosowania audytów behawioralnych, w: Promotor 2008, 1-2, s. 15. 
modyfikowania zachowań niebezpiecznych jest ustalenie celu, jaki organizacja chce osiągnąć. Pociąga to za sobą konieczność zbadania na jakim etapie znajduje się ona w chwili wdrażania programu 6 .

Audyt zachowań zakłada również obserwację fizycznego środowiska pracy, wobec czego integruje konwencjonalne i behawioralne aspekty bezpieczeństwa. Takie podejście do bezpieczeństwa pomaga modyfikować zachowania niebezpieczne również poprzez zmiany w środowisku fizycznym. Szczególnie gdy te zmiany zachodzą w krótkim czasie od momentu zgłoszenia możliwości doskonalenia w danym obszarze. Buduje to zaufanie pracowników do programu.

\section{Sposób przeprowadzenia audytu zachowań}

Pierwszym etapem w procesie audytu zachowań jest przeprowadzenie obserwacji pracownika w czasie wykonywania pracy. Obserwując pracownika, audytor analizuje sposób wykonywania pracy. Ten etap audytu może ułatwić prawidłowo opracowana lista zachowań niebezpiecznych oraz lista niebezpiecznych warunków pracy. Na tej podstawie audytor może stwierdzić:

- czy warunki, w jakich praca jest wykonywana są bezpieczne a stanowisko pracy dobrze zorganizowane i uporządkowane;

- czy pracownik posiada i stosuje odpowiednie do wykonywanej pracy środki ochrony indywidualnej;

- czy maszyny i narzędzia stosowane przez pracownika spełniają wymogi bezpieczeństwa;

- jaka jest reakcja pracownika na obecność audytora;

- czy pracownik koryguje sposób wykonywania pracy.

Kolejnym bardzo ważnym etapem audytu zachowań jest rozmowa z pracownikiem, w czasie której audytor wskazuje na zachowania niebezpieczne oraz komentuje i pochwala bezpieczne zachowania pracownika. Jednym z celów audytu zachowań jest promowanie i wzmacnianie zachowań bezpiecznych. W czasie rozmowy z pracownikiem należy poznać przyczyny niebezpiecznego zachowania. Wiedza ta jest niezbędna do prawidłowego zdefiniowania problemu, zastosowania odpowiednich działań naprawczych prowadzących w konsekwencji do doskonalenia systemu zarządzania bezpieczeństwem w danym obszarze. Dotarcie do przyczyny niebezpiecznego zachowania jest więc kluczowym czynnikiem powodzenia całego programu, ponieważ pozwala na uniknięcie niepożądanych zachowań w przyszłości.

\footnotetext{
6 Por. M. Fleming, R. LARDNER, Strategies to promote safe behaviour as part of a health and safety management system, Edinburgh, Contract research report 430/2002 for the Health and Safety Executive, 2002, ss. 9-11.
} 
Dobrze przeprowadzony audyt zachowań winien dostarczać informacji do dalszej analizy, która w konsekwencji powinna prowadzić do dokonania właściwego wyboru metody eliminacji zjawisk nieprawidłowych.

W dalszym ciągu rozmowy z pracownikiem, po uzyskaniu informacji dotyczących przyczyn, dla których pracownik wykonuje pracę w sposób niewłaściwy i niebezpieczny należy podjąć temat konsekwencji takiego postępowania.

Można wyróżnić trzy główne typy konsekwencji, które wpływają na zachowanie pracownika:

- wzmocnienie pozytywne: pochwała kierownika, uznanie kolegów, nagroda;

- wzmocnienie negatywne: uniknięcie utraty premii, uniknięcie bólu, uniknięcie kary finansowej;

- kara: utrata premii, uraz lub ból fizyczny, poczucie winy.

Zarówno pozytywne, jak i negatywne wzmocnienia mogą zwiększyć prawdopodobieństwo powtórzenia danego zachowania. Kara natomiast zmniejsza prawdopodobieństwo jego wystąpienia. W związku z tym, że wzmocnienie lub kara definiuje się poprzez efekt, coś co dla jednego pracownika jest wzmocnieniem, nagrodą dla drugiego może być karą. Jest to jeden najbardziej problematycznych aspektów we wszystkich programach modyfikacji zachowań. ${ }^{7}$

Rozmowa z pracownikiem powinna dotyczyć konsekwencji zachowań niebezpiecznych, jakie niesie za sobą niebezpieczny sposób wykonywania pracy bezpośredniego dla niego. Należy jednak tak dobrać i przedstawiać skutki zachowań niebezpiecznych, aby faktycznie zniechęcały do ich powtarzania.

Rozmowy z pracownikami wykazują, że podejmując ryzyko nie zastanawiają się oni nad skutkami swojego postępowania. Nie biorą pod uwagę, że wypadek spowodowany przez ich błąd lub świadome łamanie przepisów może mieć niebagatelne znaczenie zarówno dla nich, jak i dla ich rodzin.

Dlaczego tak łatwo przychodzi ludziom podejmowanie ryzyka? Małgorzata Milczarek stwierdza, że „(...) zachowania ryzykowne mogą być w większym stopniu 'społecznie wzmacniane' w porównaniu z zachowaniami nastawionymi na bezpieczeństwo. Takie wzmocnienia mają olbrzymią wartość szczególnie w okresie dzieciństwa i wczesnej młodości, kiedy kształtuje się osobowość oraz utrwalają pewne nawyki. Stąd często zachowania związane z ochroną własnego życia i zdrowia są uważane za mniej istotne i ich wartość musi być podkreślana za pomocą różnych interwencji lub promocji”. ${ }^{8}$

Ponadto w przedsiębiorstwach występuje zjawisko „normalizacji odchyleń”. Polega ono na sukcesywnym akceptowaniu coraz wyższego poziomu ryzyka, gdy

Por. M. Fleming, R. LARDNer, Strategies to promote safe behaviour as part of a health and safety management system, Edinburgh, Contract research report 430/2002 for the Health and Safety Executive, 2002, ss. 5-6; A. Daniels, Bringing out the best in people, New York 1999.

8 M. MilczareK, Kultura bezpieczeństwa pracy, Warszawa 2002, s. 8. 
w długim okresie nie odnotowano, w danej sytuacji, wypadku przy pracy. W konsekwencji, zachowania uważane wcześniej za ryzykowne zostają przyjęte, jako akceptowane. ${ }^{9}$

W rozmowie z pracownikiem, należy zwrócić uwagę na konsekwencje podejmowania niepotrzebnego ryzyka i celowego łamania przepisów i zasad bezpieczeństwa pracy. Działania te powinny wyjaśniać w sposób merytoryczny następstwa pracy wbrew zalecanym zasadom (np. nie stosowanie szelek bezpieczeństwa przy pracy na wysokości prowadzące do upadku z rusztowania), ale także powinny odwoływać się do sfery emocjonalnej i dotykać długoterminowych konsekwencji (utrata życia jednego z członków rodziny lub jego trwałe kalectwo).

Kształtuje to bowiem indywidualną postawę wobec bezpieczeństwa związaną z:

- przekonaniem, że różne zagrożenia mają istotny wpływ na życie i zdrowie każdego człowieka, i że poprzez odpowiednie działania można się przed nimi chronić;

- wysoką pozycją bezpieczeństwa i zdrowia w systemie wartości danego człowieka;

- rozważaniem wpływu zagrożeń nowych i nieznanych na własne zdrowie i życie;

- przyjętymi normami zachowań w zakresie stosowania się do przepisów bezpieczeństwa. $^{10}$

Pewne trudności, w naszej kulturze, występują w związku z tzw. „pochwałą ryzyka". Znajduje ona odzwierciedlenie w niektórych przysłowiach - na przykład: „do odważnych świat należy” czy „, kto nie ryzykuje, ten nie wygrywa”. Postawy związane z „pochwałą ryzyka” mogą osłabiać efekty działań prowadzonych przez organizację na rzecz kształtowania kultury bezpieczeństwa. W wielu przypadkach czynniki związane z podejmowaniem ryzyka stanowią raczej zachętę do uczestniczenia w danej sytuacji niż do jej unikania ${ }^{11}$. Rozmowa z pracownikiem na temat skutków wykonywania przez niego prac w sposób niebezpieczny jest więc zadaniem niełatwym.

$\mathrm{W}$ trakcie audytu zachowań poruszyć należy również inne aspekty związane $\mathrm{z}$ bezpieczeństwem i bezpiecznym wykonywaniem pracy w konkretnej sytuacji wzmacniając tym samym oddziaływanie na pracownika. Jeżeli audytor zauważy

9 Por. M. Milczarek, Kultura bezpieczeństwa w organizacji a zachowania bezpieczne jednostki poza praca, Warszawa 2002, s.18; N. Pidgeon, Safety Culture: key theoretical issues, w: Work \& Stress, 1998, vol.12, no 3, ss. 202-216.

10 Por. M. Milczarek, Kultura bezpieczeństwa w organizacji a zachowania bezpieczne jednostki poza praca, Warszawa 2002; N. Pidgeon, Safety Culture and Risk Management in Organizations, w: Journal of Cross-Cultural Psychology, 1991, 22, ss. 129-140.

11 Por. M. Milczarek, Kultura bezpieczeństwa w organizacji a zachowania bezpieczne jednostki poza praca, Warszawa 2002; B. Zimolong, R. TRImpop, Risk Perceptron, w: J.M. STELlman (ed.), Encyclopaedia of occupational Heath and safety, International Labour Office, Geneva 1998. 
pozytywne elementy w pracy wykonywanej przez danego pracownika, winien je podkreślić i pochwalić pracownika za rozwagę, wzmacniając tym samym bezpieczne zachowania.

Po przedstawieniu pracownikowi konsekwencji postępowania wbrew zasadom i przepisom bezpieczeństwa, audytor powinien zaproponować bezpieczny sposób wykonania zadania i uzyskać od pracownika zobowiązanie, że zarówno w danym momencie, jaki i w przyszłości będzie pracował w sposób bezpieczny. Audytor powinien przerwać wykonywanie pracy do momentu, kiedy będzie ona mogła być wykonana w sposób bezpieczny nie zagrażający zdrowiu i życiu osoby wykonującej zadanie.

Kończąc rozmowę z pracownikiem, audytor zachowań powinien podziękować za poświęcony mu czas. Audyt powinien być przeprowadzany w przyjaznej atmosferze. Nie powinny być podejmowane kroki dyscyplinarne w stosunku do pracownika, którego praca stanowi przedmiot audytu. Doprowadzi to bowiem do tego, że pracownik będzie wykonywał powierzone zadania bezpiecznie tylko widząc audytora zachowań, bądź powodowany strachem przed „przyłapaniem”. Audyt zachowań, a rozmowa z pracownikiem w szczególności, powinna stopniowo budować $\mathrm{w}$ nim przekonanie, że troska o bezpieczeństwo jest integralną częścią jego pracy.

Wyniki przeprowadzonego audytu zachowań powinny zostać udokumentowane. W przeciwnym wypadku informacji uzyskanych od pracownika nie będzie można sklasyfikować i poddać szerszej analizie. Dokument może być sporządzony w formie:

- pozytywnej listy kontrolnej gdzie obserwacje audytora będą przeciwieństwem zapisu w liście;

- negatywnej listy kontrolnej, gdzie audytor bezpośrednio zapisuje niebezpieczne zachowania zaobserwowane w czasie audytu np. brak określonych środków ochrony indywidualnej, praca niezgodna z wymogami konkretnej procedury. ${ }^{12}$

Niezależnie od tego, jaką formę zapisu zaproponuje dana organizacja, powinno być w nim miejsce na komentarz pracownika. Audytor powinien umieścić tam informacje uzyskane od pracownika związane z przyczynami wykonywania zadania w sposób niepożądany w danej organizacji. Jak już wspomniano wyżej, informacja taka jest niezbędna do podjęcia adekwatnych działań naprawczych i zapobiegawczych.

12 Por. G. Maciejewicz, BOP-ersi w stużbie BHP, w: Promotor 2008, 1-2, s. 21. 
Poniżej przykład formularza do dokumentowania audytu zachowań.

Obszar:

Data auditu :

Auditor

\section{Wskazówki dla Audytora:}

$\rightarrow$ Doceniaj, ale także egzekwuj prawidłowe zachowania ludzi

$\rightarrow$ Pytaj ludzi o zagrożenia jakie istnieją w ich miejscach pracy oraz o wiedzę nt. sposobów zapobiegania tym zagrożeniom

$\rightarrow$ Wyrażaj niepokój, jeśli widzisz zachowania niebezpieczne (np. jeśli człowiek używa szlifierki i nie chroni wzroku)

$\rightarrow$ Staraj się zrozumieć przyczyny nieprawidłowego zachowania pracownika

$\rightarrow$ Zastanawiaj się nad działaniami, które mogą poprawić sytuację

$\rightarrow$ Na koniec podziękuj rozmówcom

$\rightarrow$ Jak najszybciej odnotuj swoje spostrzeżenia w tym raporcie (zabiera to tylko ok. 10 minut!) i odeślij go na adres:

\begin{tabular}{|c|c|c|c|}
\hline \multicolumn{2}{|r|}{$\begin{array}{l}\text { Kategorie oraz przykład } \\
\text { niezgodności i zachowań }\end{array}$} & \multirow{2}{*}{$\begin{array}{l}\text { Spostrzeżenia } \\
\text { pozytywne } \\
\text { i rzeczy wymagające } \\
\text { poprawy }\end{array}$} & \multirow[t]{2}{*}{$\begin{array}{l}\text { Wymagane działania } \\
\text { i odpowiedzialni }\end{array}$} \\
\hline 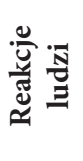 & $\begin{array}{l}\rightarrow \text { Zakładają/poprawiają środki ochrony } \\
\rightarrow \text { Zmieniają pozycję } \\
\rightarrow \text { Zmieniają sposób pracy } \\
\rightarrow \text { Przestają pracować }\end{array}$ & & \\
\hline 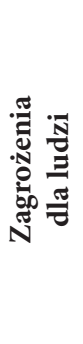 & $\begin{array}{l}\rightarrow \text { Uderzenie o coś } \\
\rightarrow \text { Uderzenie przez coś } \\
\rightarrow \text { Pochwycenie } \\
\rightarrow \text { Upadek } \\
\rightarrow \text { Kontakt z ekstremalnymi temp. } \\
\rightarrow \text { Kontakt z elektrycznością } \\
\rightarrow \text { Kontakt z chemikaliami } \\
\rightarrow \text { Zła pozycja } \\
\rightarrow \text { Dźwiganie zbyt dużego ciężaru }\end{array}$ & & \\
\hline 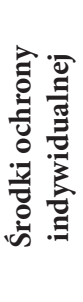 & $\begin{aligned} \rightarrow & \text { Brak ochrony głowy } \\
\rightarrow & \text { Brak ochrony oczu i twarzy } \\
\rightarrow & \text { Brak ochrony słuchu } \\
\rightarrow & \text { Brak ochrony rąk i ramion } \\
\rightarrow & \text { Brak ochrony kończyn dolnych } \\
\rightarrow & \text { Brak ochrony układ oddechowy } \\
\rightarrow & \text { Brak kamizelki/kurtki/elementów } \\
& \text { odblaskowych na odzieży }\end{aligned}$ & & \\
\hline
\end{tabular}




\begin{tabular}{|c|c|c|c|}
\hline \multicolumn{2}{|r|}{$\begin{array}{l}\text { Kategorie oraz przykład } \\
\text { niezgodności i zachowań }\end{array}$} & \multirow{2}{*}{$\begin{array}{c}\text { Spostrzeżenia } \\
\text { pozytywne } \\
\text { i rzeczy wymagające } \\
\text { poprawy } \\
\end{array}$} & \multirow[t]{2}{*}{$\begin{array}{l}\text { Wymagane działania } \\
\text { i odpowiedzialni }\end{array}$} \\
\hline 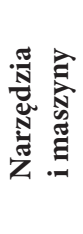 & $\begin{array}{l}\rightarrow \text { Nieodpowiednie do danej pracy } \\
\rightarrow \text { Używane nieprawidłowo } \\
\rightarrow \text { W złym stanie } \\
\rightarrow \text { Brak lub zły stan uchwytów } \\
\rightarrow \text { Nieatestowane narzędzia elektryczne } \\
\rightarrow \text { Urządzenia dźwigowe bez świadectw }\end{array}$ & & \\
\hline 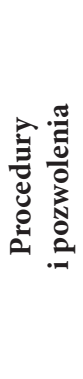 & $\begin{aligned} \rightarrow & \text { Procedury nie przestrzegane } \\
\rightarrow & \text { Procedury nieodpowiednie } \\
\rightarrow & \text { Procedury nieznane lub } \\
& \text { niezrozumiane } \\
\rightarrow & \text { Nieznane procedury postępowania } \\
& \text { dla sytuacji awaryjnych (np. pożar) } \\
\rightarrow & \text { Brak pisemnych pozwoleń na } \\
& \text { wykonywane prace (np. izolacja) lub } \\
\rightarrow & \text { Pozwolenia niedostępne w miejscu } \\
& \text { pracy }\end{aligned}$ & & \\
\hline 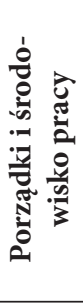 & $\begin{aligned} \rightarrow & \text { Rozłożone przewody } \\
\rightarrow & \text { Śmieci/gruz na podłodze } \\
\rightarrow & \text { Stan podłogi } \\
\rightarrow & \text { Złe oświetlenie } \\
\rightarrow & \text { Hałas } \\
\rightarrow & \text { Wysoka temperatura } \\
\rightarrow & \text { Ogólny bałagan na i wokół } \\
& \text { stanowiska }\end{aligned}$ & & \\
\hline 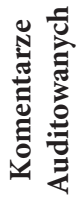 & & & \\
\hline
\end{tabular}

Każda kategoria obserwacji zawiera wskazówki dla audytora w postaci krótkich list kontrolnych, co pomaga mu zarówno dokonać obserwacji, jak i przeprowadzić rozmowę z pracownikiem oraz dokumentować spostrzeżenia.

Kategoria „reakcja ludzi” to miejsce w którym należy odnotować, jak zachowują się pracownicy widząc obserwującego ich audytora. Jeżeli pracownik pracuje niezgodnie z przyjętymi zasadami i procedurami BHP i zdaje sobie $\mathrm{z}$ tego sprawę, reaguje korekcją zachowania. W przypadku gdy nie jest świadomy, że pracuje w sposób niebezpieczny kontynuuje pracę. Zdarzają się również przypadki, kiedy pracownicy przestają pracować co może świadczyć o tym, że nie są pewni czy wykonują zadanie w sposób bezpieczny. 
Kategoria „zagrożenia dla ludzi” służy do odnotowania spostrzeżeń związanych z niebezpiecznymi warunkami, w których praca jest wykonywana np. wystające pręty, nieosłonięte ruchome części maszyn, zbyt mało miejsca na wykonanie zadania. Warunki pracy bowiem mogą być przyczyną niebezpiecznego zachowania a w konsekwencji zdarzenia wypadkowego.

Kategoria „środki ochrony indywidualnej” pozwala na odnotowanie czy w danej sytuacji pracownik stosuje odpowiednie środki ochrony, a jeżeli nie to dlaczego.

„Narzędzia i maszyny” to kategoria obserwacji dotycząca stanu, jakości, adekwatności wyboru i zgodności z wymogami wykorzystywanego w pracy sprzętu. W związku z tym, że nie wszyscy audytorzy mają przygotowanie techniczne, w czasie szkolenia podane są najbardziej charakterystyczne niezgodności związane z użytkowaniem różnego rodzaju urządzeń.

Kategoria „procedury i pozwolenia” pozwala odnotować przypadki łamania przepisów i zasad BHP określonych w procedurach i instrukcjach roboczych. Daje również możliwość określenia czy pracownicy znają wymogi i procedury. Dobrze przeprowadzona rozmowa w tym zakresie, powinna dostarczyć audytorowi informacji dlaczego pracownik znając zasady bezpiecznego postępowania świadomie je łamie.

Ostatnią kategorią obserwacji są „porządki i środowisko pracy”. Zachowania niebezpieczne mogą być bowiem wynikiem nie uporządkowania stanowiska pracy czy też bardzo trudnych warunków pracy (np. noszenie okularów ochronnych w warunkach podwyższonej temperatury).

Wszystkie przedstawione powyżej kategorie obserwacji wraz z komentarzem pracownika powinny przyczyniać się do doskonalenia systemu zarządzania bezpieczeństwem w warstwie operacyjnej, dokumentacyjnej, komunikacyjnej i szkoleniowej.

\section{Szkolenie audytorów zachowań}

Biorąc pod uwagę powyższe rozważania, istotną rolę w procesie audytu zachowań odgrywa dobór i szkolenie audytorów. W zależności od poziomu kultury bezpieczeństwa i świadomości pracowników, audytorami zachowań mogą być członkowie kadry kierowniczej wyższego i średniego stopnia, pracownicy nadzoru, jak i operatorzy maszyn. Im wyższa kultura bezpieczeństwa i zrozumienie problemów związanych $\mathrm{z}$ aspektami bezpieczeństwa tym więcej audytorów rekrutujących się z grona pracowników szeregowych.

Większość organizacji, gdzie poziom świadomości związanej z bezpieczeństwem jest niski i średni, decyduje się na rekrutację pierwszych audytorów z grona kadry kierowniczej i specjalistów. Audyty zachowań prowadzone przez członków kadry kierowniczej pokazują pracownikom zaangażowanie kierownictwa w sprawy bezpieczeństwa. Podejście kierownika do spraw bezpieczeństwa od- 
działuje, na podległych mu pracowników. Niewielkie zaangażowanie kierownika, lub wręcz łamanie przez niego przepisów BHP wpływa negatywnie na zachowanie pracowników.

Audyty zachowań prowadzone przez przedstawicieli kierownictwa wzmacniają w nich poczucie odpowiedzialności za bezpieczeństwo powierzonych im pracowników. Podkreślają, że bezpieczeństwo stanowi integralną część systemu zarządzania danym obszarem a kwestie bezpieczeństwa powinny być traktowane na równi z innymi problemami tj. budżetem, inwestycjami, zakupami i in.

Tak jak w przypadku audytorów systemów zarządzania jakością, środowiskiem czy BHP, audytor zachowań jest skuteczny tylko wtedy, kiedy rozumie założenia programu i jest przekonany o jego słuszności. Pierwsze szkolenie dla audytorów zachowań powinno więc w sposób dogłębny wyjaśniać istotę programu, jego cel i założenia. Przyszli audytorzy powinni rozumieć, jaka spoczywa na nich odpowiedzialność za powodzenie takiego programu (szczególnie, jeżeli rekrutują się z kadry kierowniczej).

Kolejnym elementem szkolenia przyszłych audytorów zachowań jest przedstawienie poszczególnych etapów audytu zachowań i wyjaśnienie czego się od nich oczekuje. Należy podkreślić rolę, jaką odgrywa dialog z pracownikiem. Gdy audytor komentuje zachowania pracowników powinien wyrażać swoje zaniepokojenie i skupiać się na zadaniu wykonywanym przez pracownika. Ważne jest podkreślenie konsekwencji niebezpiecznego zachowania pracownika dla niego, jego współpracowników czy rodziny. Pytania zadawane przez audytora powinny zmierzać do uzyskania informacji i zrozumienia przyczyn niebezpiecznego wykonywania pracy. W żadnym razie nie można oceniać działania pracownika bez analizy zaobserwowanych zjawisk.

W szkoleniu audytorów należy podkreślać różnice pomiędzy inspekcją a audytem zachowań. Pomimo, że audyt zachowań zakłada również obserwację środowiska fizycznego pracy, dotyczy przede wszystkim ludzi i skupia się na ich zachowaniach, zarówno bezpiecznych, jak i niebezpiecznych. Inspekcja jest przeważnie pasywna, gdzie rozmowa $\mathrm{z}$ pracownikiem nie ma większego znaczenia dla wyniku, podczas gdy audyt zachowań z założenia jest interaktywny. Bez rozmowy z pracownikiem nie można bowiem odnieść pożądanego efektu i doskonalić systemu zarządzania bezpieczeństwem. W audycie zachowań wymagana jest komunikacja pomiędzy audytorem i pracownikiem w formie opisanej powyżej. Inspekcję zazwyczaj prowadzą eksperci, audyt zachowań może przeprowadzić każdy, kto przeszedł szkolenie dla audytorów zachowań. Audyt zachowań może być zarówno pozytywny jak i negatywny tzn. odnosić się zarówno do zachowań i zjawisk niepożądanych, jak i tych oczekiwanych. Inspekcja z natury rzeczy skupia się na poszukiwaniu niezgodności (np. z wymogami prawnymi, procedura$\mathrm{mi}$, dobrymi praktykami itp.). W związku z tym, że różnice pomiędzy inspekcją a audytem zachowań są zasadnicze, przyszły audytor musi je znać i rozumieć, ponieważ od tego zależą wyniki jego pracy i powodzenie całego programu. 
Szkolenie audytorów zachowań powinno wyjaśniać potrzeby dokumentacyjne i oczekiwania związane z treścią dokumentu. Dobrze wypełniony dokument stanowi podstawę analizy i pomiaru niebezpiecznych zachowań, a co za tym idzie, doskonalenia systemu zarządzania bezpieczeństwem.

Szkolenie dla audytorów zachowań powinno mieć również charakter praktyczny. Ćwiczenia mogą odbywać się zarówno na terenie jednostki organizacyjnej, która wdraża program, jak i na bazie dokumentacji zdjęciowej gdzie symulowana jest rozmowa $\mathrm{z}$ pracownikiem $\mathrm{w}$ sytuacji przedstawionej na zdjęciach.

Niezbędne jest prowadzenie szkoleń odnawiających dla audytorów. Częstotliwość tych szkoleń zależy od jednostki organizacyjnej. Szkolenia tego typu są istotne z punktu widzenia programu, ponieważ pozwalają doskonalić pracę audytorów. W szkoleniach odnawiających główną rolę odgrywają sami audytorzy, dzieląc się swoimi doświadczeniami, wątpliwościami i sukcesami. Analiza konkretnych przykładów z obszaru jednostki organizacyjnej pozwala na dopracowanie metody prowadzenia audytów a tym samym podniesienie ich skuteczności.

Podsumowując powyższe rozważania jeszcze raz należy podkreślić, iż powodzenie programu modyfikacji zachowań niebezpiecznych pracowników zależy w dużej mierze od prawidłowego określenia warunków wyjściowych. Nie można jednak zapominać o tym, że programy modyfikowania zachowań niebezpiecznych stanowią jeden $\mathrm{z}$ elementów zarządzania bezpieczeństwem winny więc podlegać ciągłemu doskonaleniu.

\section{Zakończenie}

Aspekty behawioralne winny być uwzględniane w systemie zarządzania bezpieczeństwem w organizacji. Audyt zachowań staje się praktycznym narzędziem, dzięki któremu możliwe jest ujawnienie niedostatków systemu zarządzania BHP. Umożliwia jednak określenie strategii jego doskonalenia np. w warstwie dokumentacyjnej, szkoleniowej, komunikacyjnej czy operacyjnej. Zachowania pracowników, w tym kontekście, są wskaźnikiem efektywności systemu zarządzania bezpieczeństwem i higieną pracy.

Program uwzględniający behawioralne aspekty bezpieczeństwa w procesie zarządzania BHP ma na celu modyfikację zachowań niebezpiecznych. Nie może on zastępować konwencjonalnych i stosowanych dotychczas metod zarządzania w tym obszarze, stanowi jednak znakomite ich uzupełnienie. Audyt zachowań jest praktyczną metodą pozyskiwania informacji na temat wybranych elementów określonego obszaru interesującego z punktu widzenia zarządzania nim. Elastyczność współczesnych systemów zarządzania umożliwia ich integrację. Interesująco przedstawia się zatem możliwość wykorzystania prezentowanej metody audytu lub jej wyników w zarządzaniu innymi obszarami. 
W procesie audytu zachowań uwzględnia się bezpieczeństwo człowieka w jego środowisku. Przedmiot i cel tego procesu zawierają się zarówno w systemie zarządzania bezpieczeństwem i higieną pracy jak i systemie zarządzania środowiskowego organizacji. Jak już wspomniano, szerokie rozumienie terminu „środowisko" nie pozwala ograniczać się do jednego tylko typu otoczenia, w którym funkcjonuje człowiek. Metody zaprezentowane w niniejszym artykule mogłyby być (do)stosowane do wielu różnych typów otoczenia. Tym samym audyt zachowań mógłby stanowić element integrujący określone systemy zarządzania.

Interesująca może być próba wykorzystania metody audytu zachowań w systemie zarządzania środowiskowego organizacji. Jak się wydaje możliwe są w tym przypadku dwa rozwiązania. Pierwsze polegałoby na włączaniu w proces audytu zachowań niebezpiecznych, prowadzonego $\mathrm{w}$ ramach systemu zarządzania bezpieczeństwem i higieną pracy, wybranych (kluczowych w określonych okolicznościach) zachowań niebezpiecznych dla człowieka w kontekście jego wpływu na środowisko przyrodnicze. W drugim przypadku należałoby uwzględnić możliwość zaadoptowania opisanej metody do systemu zarządzania środowiskowego i wprowadzić np. audyt zachowań niebezpiecznych dla środowiska przyrodniczego.

Należy podkreślić, że wiele metod i narzędzi służących do gromadzenia i analiz informacji odwołuje się jedynie do deklaracji badanych. Stanowi to często o niedoskonałości takich metod (szczególnie w obrębie nauk społecznych, socjologii, psychologii itp.). Szczególnym przykładem może być, w tym przypadku, badanie „świadomości ekologicznej”. Metody stosowane w tym zakresie (ankieta, wywiad) pozwalają na uzyskanie deklaracji (chęci) postępowania - nie koniecznie informacji o samym postępowaniu, które jest wynikiem świadomych wyborów. Przedmiotem prezentowanej formy audytu jest natomiast działanie i faktyczne zachowanie człowieka w otoczeniu. Celem natomiast zbieranie informacji, dzięki którym możliwe będzie ciągłe doskonalenie systemu zarządzania bezpieczeństwem i higieną pracy a tym samym poprawa bezpieczeństwa człowieka $\mathrm{w}$ jego otoczeniu. Skutkiem prowadzonych działań winna być zmiana postępowania. Ze względu na proponowaną metodologię prowadzenia audytu zachowań nie występuje problem „deklaratywności” gromadzonych informacji. Problemy związane z prowadzeniem audytu zachowań mogą polegać na ograniczeniach czasowych, rozległości obserwowanych obszarów, możliwości rzetelnej obserwacji określonej liczby osób lub złym przygotowaniu audytora. Niemniej, w obrębie organizacji, istnieje możliwość rzetelnego przeprowadzenia tej formy audytu. 


\title{
A behavioural audit as a tool of the Health and Safety Management Systems
}

\begin{abstract}
SUMMARY
In the article there were presented general assumptions concerning employees' hazardous behaviour modification programme with use of a behavioural audit. The author depicted a method of the audit conduct underlining the meaning of a dialogue with an employee for proper identification of reasons for hazardous behaviours. Therefore, a crucial role of auditors' selection and training was emphasised for they deliver data for further analysis. The quality of data obtained in the behaviour and work conditions observation process is vital for the programme success. Consequently, periodic trainings for behavioural auditors need to be carried out to deepen their knowledge and improve the methods of auditing.
\end{abstract}

